\title{
Diesel biodegradation capacities of indigenous bacterial species isolated from diesel contaminated soil
}

\author{
Nandhini Palanisamy ${ }^{1}$, Jayaprakash Ramya ${ }^{1}$, Srilakshman Kumar ${ }^{1}$, NS Vasanthi ${ }^{1}$, Preethy Chandran ${ }^{2}$ \\ and Sudheer Khan ${ }^{1,2^{*}}$
}

\begin{abstract}
Petroleum based products are the major source of energy for industries and daily life. Leaks and accidental spills occur regularly during the exploration, production, refining, transport, and storage of petroleum and petroleum products. In the present study we isolated the bacteria from diesel contaminated soil and screened them for diesel biodegradation capacity. One monoculture isolate identified by 165 rRNA gene sequence analysis to be Acinetobacter baumannii was further studied for diesel oil biodegradation. The effects of various culture parameters $(\mathrm{pH}$, temperature, $\mathrm{NaCl}$ concentrations, initial hydrocarbon concentration, initial inoculum size, role of chemical surfactant, and role of carbon and nitrogen sources) on biodegradation of diesel oil were evaluated. Optimal diesel oil biodegradation by $A$. baumanii occurred at initial $\mathrm{pH} 7,35^{\circ} \mathrm{C}$ and initial hydrocarbon concentration at $4 \%$. The biodegradation products under optimal cultural conditions were analyzed by GC-MS. The present study suggests that $A$. baumannii can be used for effective degradation of diesel oil from industrial effluents contaminated with diesel oil.
\end{abstract}

Keywords: Acinetobacter baumannii, Diesel oil, Parameter optimization, Biodegradation, GC-MS analysis

\section{Introduction}

Increasing industrial activities and technological progress have demanded a drastic increase in the use of petroleum hydrocarbons. There is considerable risk of environmental contamination during extraction, transportation, refining, storage, usage and ultimate disposal of these non-aqueous phase liquids composed of a large number of hazardous and toxic constituents [1]. Marine and subsurface environment contamination has been reported due to accidental leakage of ships, cars, trucks, etc., leaks and spills from underground storage tank, pipelines and illegal disposals.

Diesel oil, a complex hydrocarbon pollutant is a mixture of alkanes and aromatic compounds that are reported frequently as soil contaminants [2]. One of the best approaches to restoring contaminated soil is to make use of microorganisms able to degrade those toxic

\footnotetext{
* Correspondence: ssudheerkhan@gmail.com

'Department of Biotechnology, Bannari Amman Institute of Technology, Sathyamangalam, Tamil Nadu, India ${ }^{2}$ CeNTAB, School of Chemical and Biotechnology, SASTRA University,
Thanjavur 613401, Tamil Nadu, India ${ }^{2}$ CeNTAB, School of Chemical and Biote
Thanjavur 613401, Tamil Nadu, India
}

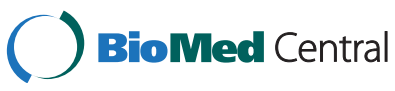

(c) 2014 Palanisamy et al.; licensee BioMed Central Ltd. This is an Open Access article distributed under the terms of the Creative Commons Attribution License (http://creativecommons.org/licenses/by/2.0), which permits unrestricted use, distribution, and reproduction in any medium, provided the original work is properly credited. The Creative Commons Public Domain Dedication waiver (http://creativecommons.org/publicdomain/zero/1.0/) applies to the data made available in this article, unless otherwise stated. compounds in a bioremediation process [3]. Bioremediation is a cost effective approach for cleaning up petroleum hydrocarbons from contaminated area because it is simple to maintain, applicable over large areas and leads to the complete destruction of the contaminant [4]. Bioremediation of these pollutants are significantly affected by the inherent capabilities of the microorganisms to overcome the bioavailability limitations in multiphase environmental scenarios (oil-water-soil) and environmental factors such as temperature, $\mathrm{pH}$, nutrients and electron acceptor availability [5].

The present study employed bacteria isolated from diesel contaminated soil for the biodegradation of diesel oil. Culture parameters for efficient degradation of diesel oil by a bacterial isolate were optimized.

\section{Materials and methods Materials}

Diesel oil used in this study was obtained from local petrol bunk, Tamil Nadu, India and sterilized by filter

a 
sterilization. All other chemicals used in the present study were of highest purity in grade.

\section{Isolation, screening and identification}

Bacterial species were isolated from diesel contaminated soil (petrol bunk, lorry shed, bus shed and automobile garage) from Sathyamangalam, Tamil Nadu, India [6,7]. Soil samples were serially diluted, $100 \mu \mathrm{L}$ of the diluted samples spread on the surface of nutrient agar plates and the plates incubated at $37^{\circ} \mathrm{C}$ for $24 \mathrm{~h}$. The colonies obtained from the agar plates were further sub-cultured to obtain the pure colonies. The bacterial species were screened based on the ability of the bacterial species to degrade diesel oil. The degradation studies were performed in Mineral Salt Medium (MSM) that contains diesel oil as the sole source of carbon. The MSM consists of $\mathrm{NH}_{4} \mathrm{NO}_{3}-3 \mathrm{~g} / \mathrm{L}, \mathrm{KH}_{2} \mathrm{PO}_{4}-0.5 \mathrm{~g} / \mathrm{L}$, $\mathrm{K}_{2} \mathrm{HPO}_{4} \cdot 3 \mathrm{H}_{2} \mathrm{O}-0.5 \mathrm{~g} / \mathrm{L}$ and trace amounts of $\mathrm{MgSO}_{4} \cdot 7 \mathrm{H}_{2} \mathrm{O}-0.008 \mathrm{~g} / \mathrm{L}, \mathrm{CuSO}_{4} \cdot 4 \mathrm{H}_{2} \mathrm{O}-0.002 \mathrm{~g} / \mathrm{L}$, $\mathrm{MnSO}_{4 .} \mathrm{H}_{2} \mathrm{O}-0.002 \mathrm{~g} / \mathrm{L}, \mathrm{FeSO}_{4 .} .7 \mathrm{H}_{2} \mathrm{O}-0.002 \mathrm{~g} / \mathrm{L}$ and $\mathrm{CaCl}_{2} .2 \mathrm{H}_{2} \mathrm{O}-0.002 \mathrm{~g} / \mathrm{L}$. The isolated bacterial species from different sites were cultured in Mineral Salt Medium containing diesel oil and incubated for 3 days at $37^{\circ} \mathrm{C}$. The growths of the isolated bacterial species were monitored at regular intervals by measuring the optical density at $600 \mathrm{~nm}$. Based on the growth of bacterial species on diesel oil degradation, the best degrader of diesel oil was selected and identified by $16 \mathrm{~S}$ rRNA gene sequence analysis and used for further studies. Polymerase chain reaction (PCR) was conducted using $16 \mathrm{~S}$ rRNA forward primer: AGA GTT TGA TCC TGG CTC AG and 16S rRNA reverse primer: ACG GCT ACC TTG TTA CGA CTT. The sequence of the PCR amplicon was submitted to GenBank to obtain accession number. NCBI BLASTN 2.2.26+ comparison software was used to reveal the identities of the isolate.

\section{Effect of $\mathrm{pH}$}

The bacterial species were cultured in Luria Bertani (LB) broth and incubated at $37^{\circ} \mathrm{C}$ for $24 \mathrm{~h}$. Then the culture was centrifuged at $5000 \times \mathrm{g}$ for $10 \mathrm{~min}$, the pellets were collected and washed twice with saline to remove the trace amount of LB medium. To study the effect of $\mathrm{pH}$ on degradation, MSM supplemented with $1 \%$ of diesel oil was adjusted to different initial $\mathrm{pH}$ 4-11 using $\mathrm{HCl}$ or $\mathrm{NaOH}$. Two hundred and fifty milliliter Erlenmeyer conical flasks containing $100 \mathrm{~mL}$ MSM were inoculated with $2 \mathrm{~mL}$ of $1.5 \mathrm{OD}$ inoculum size of strain and incubated at $37^{\circ} \mathrm{C}$ under shaking condition $(120 \mathrm{rpm})$. In the Control, without the inoculation of bacterial species was kept under similar condition. Samples were collected at regular intervals of time $(6 \mathrm{~h})$ up to $120 \mathrm{~h}$.

\section{Effect of temperature}

The bacterial species was cultured in LB broth and was incubated at $37^{\circ} \mathrm{C}$ for $24 \mathrm{~h}$. Then the culture was centrifuged at $5000 \times \mathrm{g}$ for $10 \mathrm{~min}$, the pellets were collected and washed twice with saline to remove the trace amount of LB medium. To study the effect of temperature on degradation, MSM supplemented with $1 \%$ of diesel oil was incubated to different temperature such as $25,30,35,40$ and $45^{\circ} \mathrm{C}$ for optimizing the temperature. Two hundred and fifty milliliter Erlenmeyer conical flasks were inoculated with 1.5 optical density inoculum size which was prepared by diluting the bacterial culture with $0.9 \% \mathrm{NaCl}$ and optical density value was adjusted to 1.5 using colorimeter. Flasks were kept under shaking condition (120 rpm). At regular intervals, the growth of the bacterial species was measured by recording the absorbance at $600 \mathrm{~nm}$. In the control experiments, the flask containing inoculum devoid of diesel oil and the flasks containing diesel oil devoid of inoculum were run parallel at similar conditions.

\section{Effect of initial hydrocarbon concentration}

To study the effect of initial hydrocarbon concentration on degradation, MSM supplemented with different concentrations of diesel oil such as 1-5\% was used as substrate. The flasks were inoculated with strain and incubated at $37^{\circ} \mathrm{C}$ under shaking condition (120 rpm). In the controls, without inoculation of strain were kept under similar conditions with inoculated flasks. Samples were collected at regular intervals of time $(6$ h) up to $120 \mathrm{~h}$ and analyzed for residual diesel oil.

\section{Effect of initial inoculum size}

To study the effect of initial inoculum concentration on degradation, MSM supplemented with $1 \%$ of diesel oil was inoculated with different inoculum quantity such as 0.1, 0.6, 1 and 1.5 OD (Absorbance at $600 \mathrm{~nm}$ ). Two hundred and fifty milliliter Erlenmeyer conical flasks were incubated at $37^{\circ} \mathrm{C}$ under shaking condition (120 rpm). In the controls, without inoculation of strain were kept under similar conditions with inoculated flasks. Samples were collected at regular intervals of time $(6 \mathrm{~h})$ up to $120 \mathrm{~h}$.

\section{Role of chemical surfactants}

To study the role of chemical surfactants on degradation, MSM supplemented with $4 \%$ of diesel oil along with $0.02 \%(\mathrm{w} / \mathrm{v}) /(\mathrm{v} / \mathrm{v})$ of different surfactants such as sodium dodecyl sulfate (SDS) and Tween 80 for enhancing the degradation. Two hundred and fifty milliliter Erlenmeyer conical flasks were inoculated with 1.5 OD inoculum size of strain flasks were inoculated with strain and incubated at $37^{\circ} \mathrm{C}$ under shaking condition (120 rpm). In the controls, without inoculation of strain, were kept under similar conditions with inoculated 
flasks. Samples were collected at regular intervals of time (6 h) up to $120 \mathrm{~h}$.

\section{Role of $\mathrm{NaCl}$ concentration}

To study the role of $\mathrm{NaCl}$ concentration on degradation, MSM supplemented with $4 \%$ of diesel oil along with different concentrations of $\mathrm{NaCl}$ such as $1 \mathrm{mM}, 100 \mathrm{mM}$, $500 \mathrm{mM}, 1 \mathrm{M}, 2 \mathrm{M}$ and $5 \mathrm{M}$ for checking the salinity condition. Two hundred and fifty milliliter Erlenmeyer conical flasks were inoculated with 1.5 OD inoculum size of bacterial culture. Flasks were inoculated with the bacterial strain and incubated at $37^{\circ} \mathrm{C}$ under shaking condition $(120 \mathrm{rpm})$. In the controls, without inoculation of strain, were kept under similar conditions with inoculated flasks. Samples were collected at regular intervals of time $(6 \mathrm{~h})$ up to $120 \mathrm{~h}$.

\section{Effect of carbon and nitrogen sources}

To study the effect of carbon and nitrogen sources on degradation, MSM supplemented with $4 \%$ of diesel oil along with $0.1 \%$ of carbon source such as Dextrose, Maltose and $0.1 \%$ of nitrogen source such Peptone and Yeast extract. Two hundred and fifty milliliter Erlenmeyer conical flasks were inoculated with 1.5 optical density inoculum size of strain was incubated at $37^{\circ} \mathrm{C}$ under shaking condition $(120 \mathrm{rpm})$. In the controls, without inoculation of strain, were kept under similar condition with inoculated flasks. Samples were collected at regular intervals of time $(6 \mathrm{~h})$ up to $120 \mathrm{~h}$.

\section{Gas Chromatography- Mass Spectrometry (GC-MS) analysis}

GC-MS analysis was done for detecting the degradation effect of diesel oil [8]. After the incubation period, $5 \mathrm{~mL}$ of the cultures were extracted with two $20 \mathrm{~mL}$ volumes of $\mathrm{n}$-hexane as a solvent by using separating funnels to remove cellular material. The residues were transferred to tarred vials and the volume of each extract was adjusted to $100 \mathrm{~mL}$ by adding further $\mathrm{n}$-hexane. The vials were kept at $4^{\circ} \mathrm{C}$ until the gas chromatographic analysis. Uninoculated control was incubated in parallel to monitor abiotic losses of the substrate.

The degradation effect of diesel oil was detected by GCMS (Thermo GC- Trace Ultra ver: 5.0, Thermo MS DSQ II), which was equipped with a DB 35- MS Capillary Standard Non-polar column $(30 \mathrm{~m} \times 0.25 \mathrm{~mm} \times 0.25 \mu \mathrm{m})$. 1 microliter of the organic phase was analyzed by GC-MS. The gas chromatograph equipped with a split-split less injector (split ratios of 50:1) was used for the GC-MS analysis. The oven temperature was initially at $40^{\circ} \mathrm{C}$ and then programmed to $270^{\circ} \mathrm{C}$ at a rate of $8^{\circ} \mathrm{C} / \mathrm{min}$ where it was held for $5 \mathrm{~min}$. The temperatures of injector, transfer line and ionization source were all $250^{\circ} \mathrm{C}$. The electron impact ionization was tuned at $70 \mathrm{eV}$ and Helium was used as carrier gas with an average linear velocity of $1.0 \mathrm{~mL} / \mathrm{min}$.

\section{Results and discussion}

Biodegradation capacity can be evaluated by performing a laboratory study or extensive waste characterization are put together with the bioremediation potential which depends on biodegradability of a specific type of hydrocarbon compound. In this section, isolation of pure cultures and effect of various parameters on hydrocarbon degradation, such as $\mathrm{pH}$, temperature, $\mathrm{NaCl}$ concentration, initial hydrocarbon concentration, initial inoculums size, different carbon and nitrogen sources, and chemical surfactant were reported. The roles of biosurfactant effect in contaminant solubilization and biodegradation experiments also have been documented.

\section{Isolation and identification of bacterial species}

The isolated bacterial strain was screened based on the ability to utilize diesel oil. The isolate was identified by 16s rRNA analysis and the organism was Acinetobacter baumannii (Accession No. JQ975035). It utilizes hydrocarbons as the sole source of carbon and degrades it to maximum extent. Haritash and Kaushik [9] demonstrated that microorganisms are the main degraders of hydrocarbons. There are various abiotic factors which were optimized for maximum degradation of diesel oil.

\section{Effect of $\mathrm{pH}$}

Effect of $\mathrm{pH}$ for growth of A. baumannii with diesel oil was evaluated. The A. baumannii showed maximum growth in $\mathrm{pH}$ 7. The growth of the bacterial species was decreased while decreasing or increasing the $\mathrm{pH}$. Hence it is understood that neutral $\mathrm{pH}$ is required for optimum growth of bacteria, acidic and basic conditions did not favour the growth of $A$. baumannii. Figure 1 shows the growth of bacterial species at different $\mathrm{pH}$ in MSM containing 1\% diesel oil. According to Whang et al. [10] microbial growth and diesel biodegradation was found to be at a $\mathrm{pH} 7.2$, while decreasing or increasing the $\mathrm{pH}$ reduced the degradation efficiency considerably. Xia et al. [11] studied the effect of $\mathrm{pH}$ on diesel degradation through the response surface methodology (RSM) using a central composite design and they found the and the optimal biodegradation conditions of diesel oil was $\mathrm{pH}$ 7.4. According to Luo et al. [12] at $\mathrm{pH}$ level of 7 Pseudomonas sp. strain F4 showed efficient diesel oil degradation potential. Hence, the optimization of $\mathrm{pH}$ is very important for the enhanced growth of bacteria and also for selection of effective bioremediation strategy. Sathishkumar et al. [13] reported that the optimum $\mathrm{pH}$ for the degradation of crude oil by individual bacterial strains and a mixed bacterial consortium was found to be 7 . 


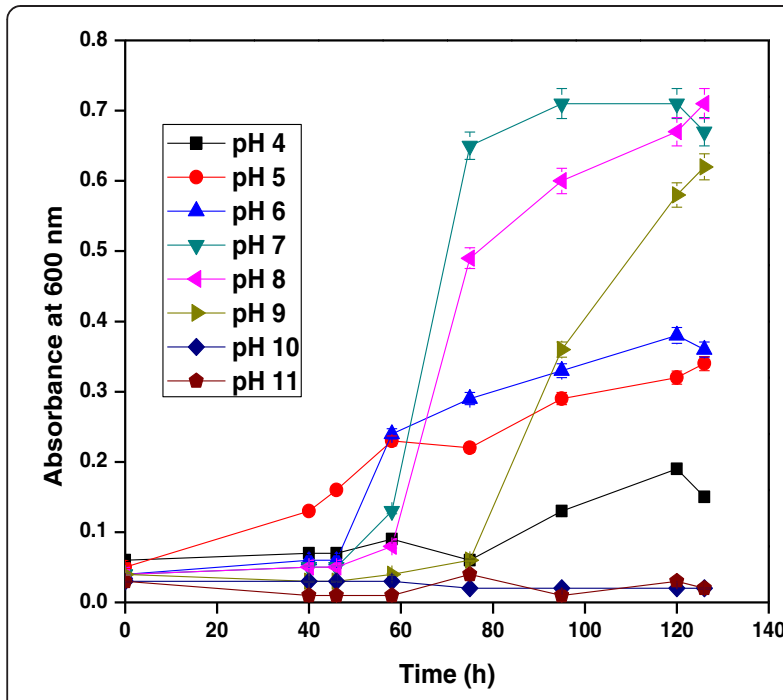

Figure 1 Effect of $\mathrm{pH}$ for growth of $A$. baumannii using diesel oil at $35^{\circ} \mathrm{C}$.

\section{Effect of temperature}

Effect of temperature for growth of A. baumannii with diesel oil was evaluated. We found that temperature is an important factor that affects the diesel degradation potential by bacteria. Mnif et al. [14] found that $30^{\circ} \mathrm{C}$ was the optimum condition for the degradation of diesel by Bacillus subtilis SPB1. Same time, the diesel oildegrading ability of Pseudomonas sp. strain F4 was reported to be $37^{\circ} \mathrm{C}$ [12]. The present study analyzed the optimum temperature for the degradation of diesel oil and it was found maximum at $35^{\circ} \mathrm{C}$. The minimum growth was observed at $45^{\circ} \mathrm{C}$. Maintenance of temperature is as important as $\mathrm{pH}$ which strongly affects bacterial growth. The growth of $A$. baumannii was directly proportional to diesel oil degradation, since the medium with diesel oil as the sole source of carbon. The degradation efficiency decreased greatly with the increase of temperature. Figure 2 shows the growth of bacterial species at different temperature in MSM containing $1 \%$ diesel oil.

\section{Effect of initial hydrocarbon concentration}

Effect of initial hydrocarbon concentration for growth of A. baumannii with diesel oil was evaluated. Initial hydrocarbon concentrations of 1-5\% were used for this degradation studies in which MSM containing $4 \%$ of diesel oil showed maximum growth of A. baumannii, as shown in Figure 3. Minimum growth of bacterial species was observed in $1 \%$ concentration of initial hydrocarbon. At high diesel oil concentration, diesel oil provided a better carbon source for the growth of bacteria Luo et al. [15]. The growth of the bacterial species was increased with increase in diesel concentration. The bacterial species did not possess higher growth at above $4 \%$

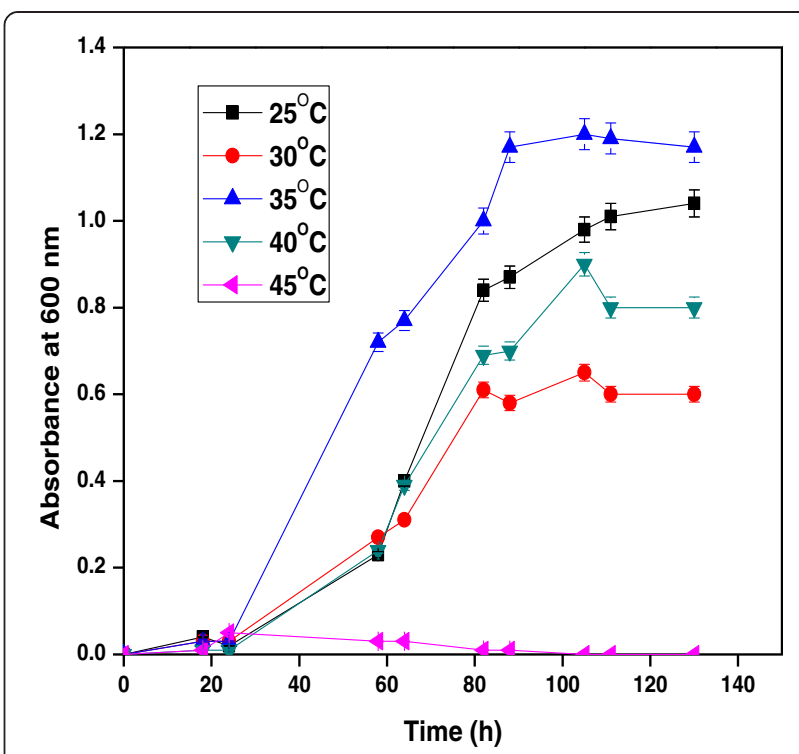

Figure 2 Effect of temperature for growth of $A$. baumannii using diesel oil at $\mathrm{pH} 7$.

diesel oil concentration. The reason for decreased consumption of diesel oil at high concentration may be attributed due to stress of hydrocarbons on bacterial species.

\section{Effect of initial inoculum size}

Effect of initial inoculum size for growth of A. baumannii with diesel oil was evaluated. MSM medium was inoculated with initial inoculum concentration of 0.1, 0.6, 1.0 and 1.5 optical density measured at $600 \mathrm{~nm}$. Figure 4 shows the effect of inoculum quantity of bacterial species

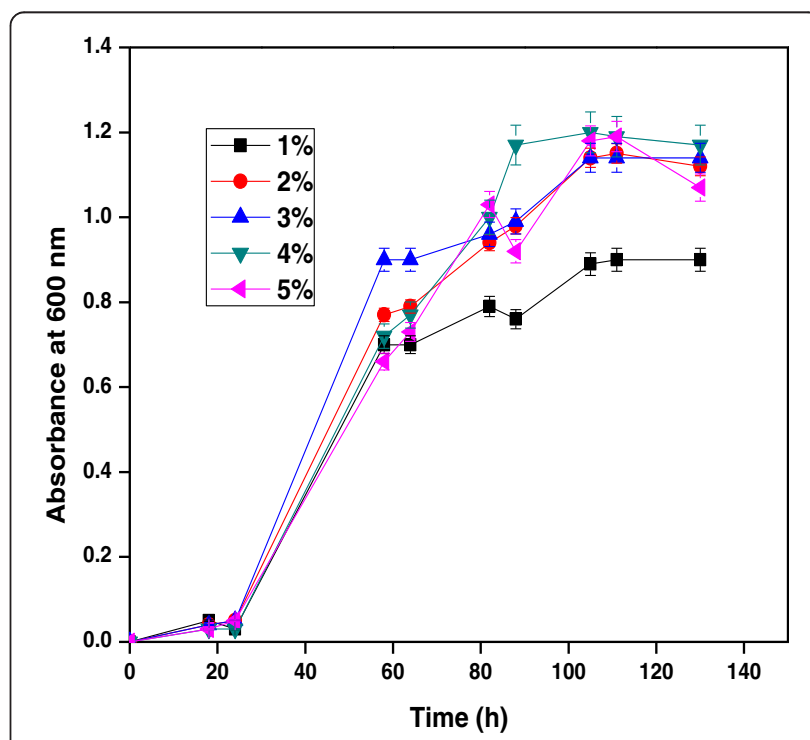

Figure 3 Effect of initial hydrocarbon concentration for growth of $A$. baumannii using diesel oil at $\mathrm{pH} 7$ and $35^{\circ} \mathrm{C}$. 


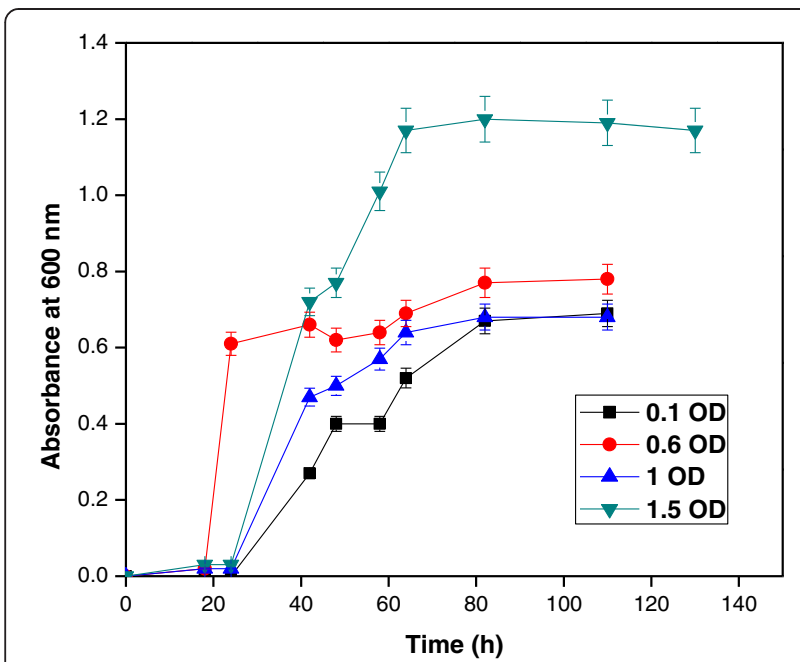

Figure 4 Effect of initial inoculum concentration for growth of A. baumannii using diesel oil at $\mathrm{pH} 7$ and $35^{\circ} \mathrm{C}$.

on diesel oil degradation. The removal of hydrocarbon mainly depends on the capabilities of the microorganisms [16]. When inoculum of A. baumannii increased up to 1.5 optical density, lag period for growth of strain decreased and subsequently resulted in higher growth indicates higher diesel oil degradation as depicted in Figure 4. Pseudomonas sp. showed efficient diesel degradation efficiency when the inoculums size was adjusted to $2 \%(\mathrm{v} / \mathrm{v})$ [12]. Luo et al. [15] shows that when the bacteria concentration was $4 \times 10^{7}$ cells $/ \mathrm{mL}$, the cell density and biodegradation rate were all the highest after seven days incubation. The removal of hydrocarbon mainly depends on the capabilities of the microorganisms. Lakshmi et al. [17] reported that immobilized $\left(18.6 \times 10^{6} \mathrm{cells} / \mathrm{mL}\right)$ and free cells of Mycoplana sp. MVMB2, a soil isolate was able

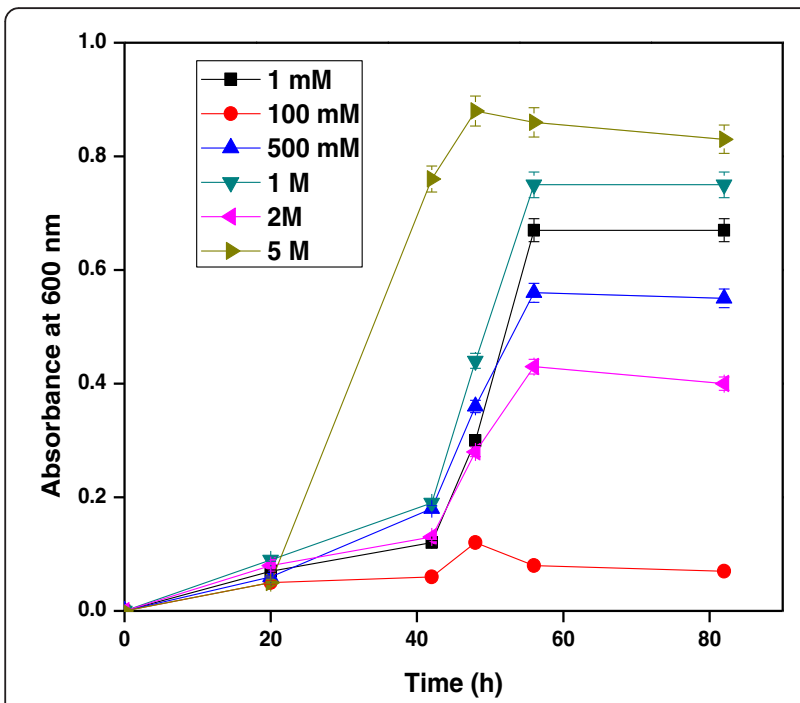

Figure 5 Role of $\mathrm{NaCl}$ concentration for growth of $A$. baumannii using diesel oil at $\mathrm{pH} 7$ and $35^{\circ} \mathrm{C}$.

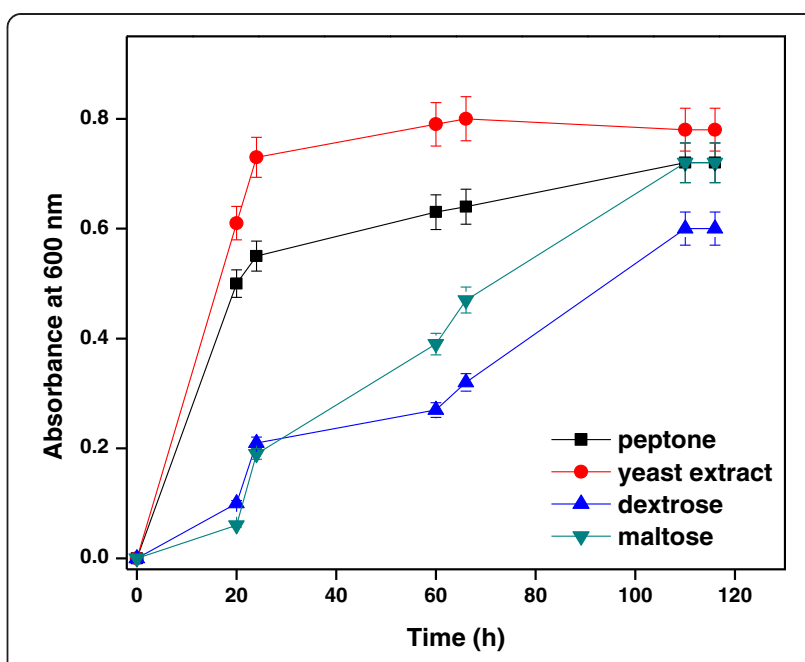

Figure 6 Effect of carbon and nitrogen sources for growth of A. baumannii using diesel oil at $\mathrm{pH} 7$ and $35^{\circ} \mathrm{C}$.

to degrade $95 \%$ phenanthrene within $72 \mathrm{~h}$ and $120 \mathrm{~h}$ respectively.

\section{Effect of $\mathrm{NaCl}$ concentrations}

Effect of $\mathrm{NaCl}$ concentration for growth of A. baumannii with diesel oil was evaluated. Metabolic capacities of the bacterial species with respect to salinity were tested for degradation of diesel oil. A. baumannii was degraded in the presence of $1 \mathrm{mM}, 100 \mathrm{mM}, 500 \mathrm{mM}, 1 \mathrm{M}, 2 \mathrm{M}$ and 5 $\mathrm{M} \mathrm{NaCl}$ concentration. Increase in $\mathrm{NaCl}$ concentration increases the growth of the bacteria in MSM containing 4\% diesel oil. Figure 5 shows that variations in salinity had a strong influence on biodegradation which progressively increased when salinity increased. This would be particularly appropriate for removal of stranded oil on beaches or intertidal areas where bacterial species would have to

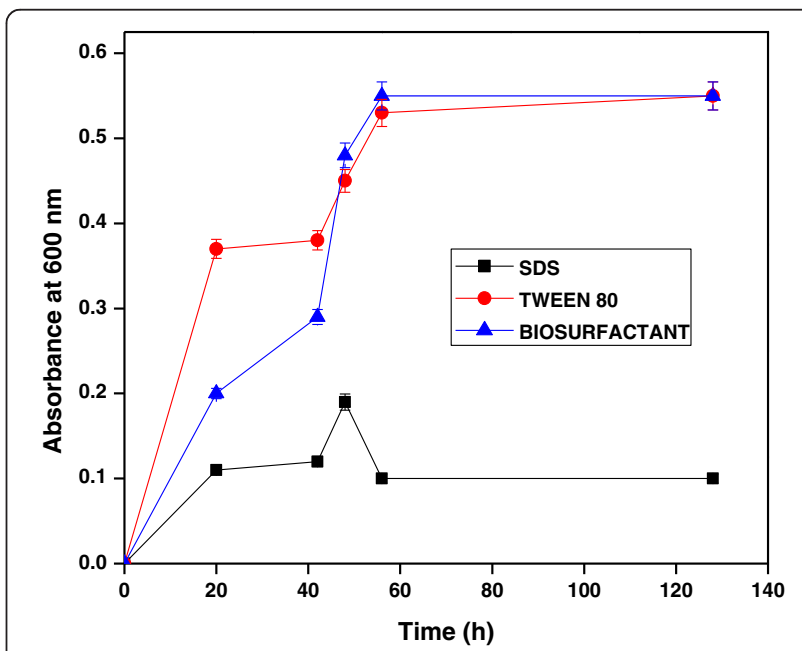

Figure 7 Role of surfactants for growth of $A$. baumannii using diesel oil at $\mathrm{pH} 7$ and $35^{\circ} \mathrm{C}$. 
survive exposure to high concentrations of sodium chloride, or in estuarine areas where salinity gradients occur. Mnif et al. [18] isolated a novel aromatic-degrading bacterium from a geothermal oil field under saline and thermophilic conditions and the optimum $\mathrm{NaCl}$ concentration for degradation was found to be $10 \mathrm{~g} / \mathrm{L}$.

\section{Role of carbon and nitrogen sources}

Role of carbon and nitrogen sources for growth of A. baumannii with diesel oil was evaluated. Various carbon and nitrogen sources such as dextrose, maltose, yeast extract and peptone $(0.1 \%)$ were added to the MSM medium containing 4\% diesel oil as nutrient addition for diesel oil degradation, amongst them peptone and yeast extract were found to enhance diesel oil degradation). Prathima Devi et al [19] reported that addition of external nutrients enhance the degradation of crude petroleum sludge. As shown in Figure 6, growth of A. baumannii was increased in the presence of peptone within $120 \mathrm{~h}$. Consequently, peptone was selected as the
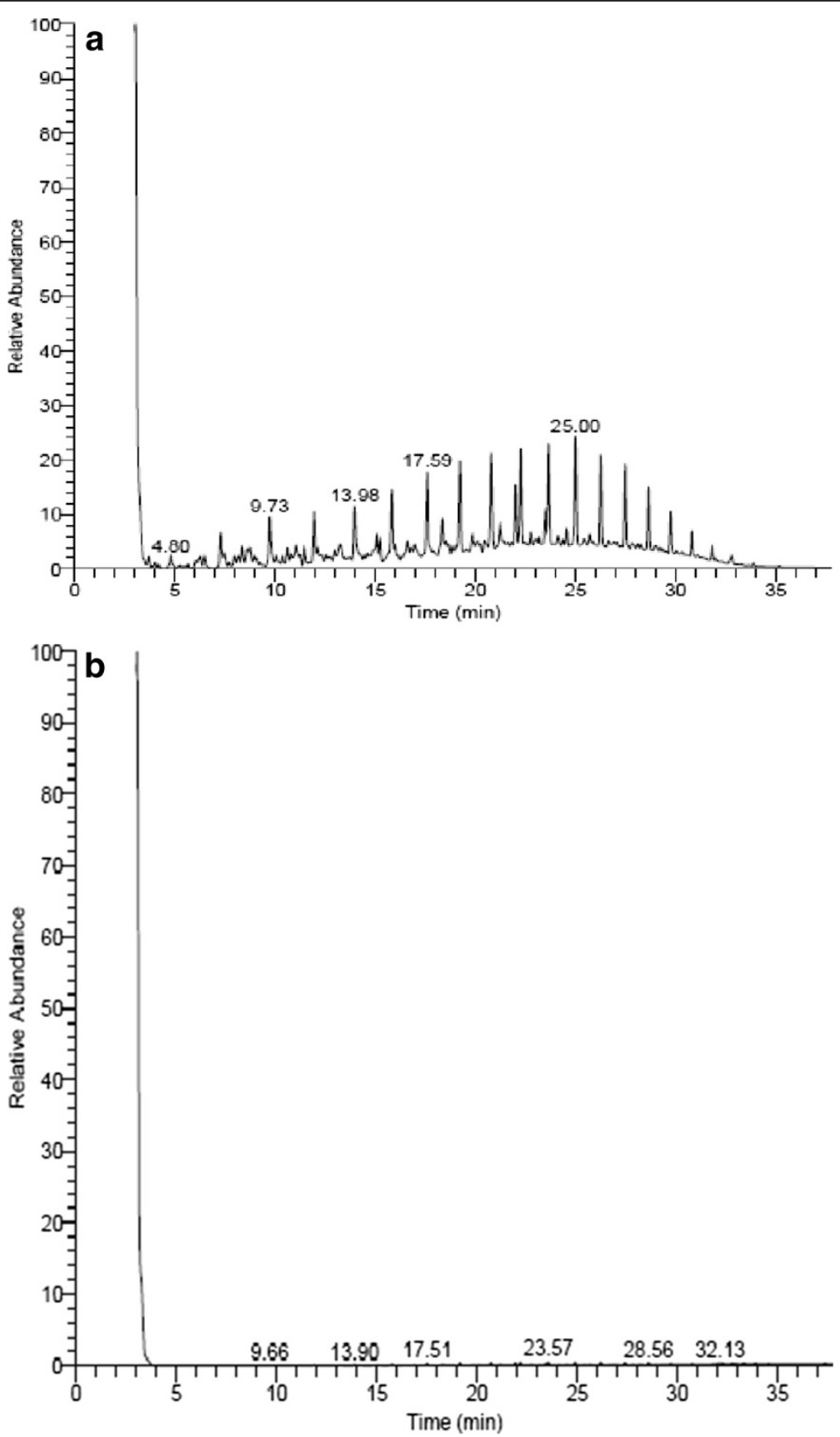

Figure 8 a: GC-MS profile for control diesel oil and b: GC-MS profile for diesel oil after biodegradation by A. baumannii. 
nitrogen source for further studies. The addition of glucose caused a significant difference in the ability of the diesel degraders to break down diesel of up to $84 \%$ [20]. Zahed at al. [21] reported that crude oil removal of $69.5 \%$ was observed in presence of $16.05 \mathrm{mg} / \mathrm{L}$ nitrogen. Liu et al. [22] reported that addition of carbon source increased the rate of degradation of hydrocarbon by Rhodococcus sp. demonstrated that minerals or supplementary carbon substrates increase the rate of biodegradation. $\mathrm{NH}_{3}$ may be used by microbes as a source of $\mathrm{N}$ which undergo nitrification and volatilize. $\mathrm{NO}_{3}{ }^{-}+\mathrm{NO}_{2}{ }^{-}$may be used by microbes as a source of $\mathrm{N}$, undergo denitrification [23]. Carbon sources were not utilized by the bacterial species at earlier stage and there was minimum growth in the presence of carbon sources.

\section{Effect of chemical surfactants}

The effect of surfactants (chemical and biological) on diesel oil degradation by bacterial strain is depicted in Figure 7. Tween 80, SDS and biosurfactant enhanced the growth of bacterial species within $72 \mathrm{~h}$ compared to the growth of bacterial species without surfactants. However, addition of non-ionic surfactants did not show any significant increase in diesel oil degradation in comparison to control (without surfactants). Bautista et al. [24] had also reported that Tween 80 was the best amongst non-ionic surfactants in improving the degradation of PAHs.

Possibly, A. baumannii produced biosurfactants, which increased pseudo solubilization of diesel oil in the medium.

\section{GC-MS analysis}

The biodegradation of diesel oil by A. baumannii was confirmed by GC-MS analysis. GC-MS chromatogram showed reduction in the intensity of diesel oil peaks after the degradation with $A$. baumannii when compared with control diesel oil (Figure 8). The study shows that $A$. baumannii was able to degrade $>99 \%$ of the diesel oil within 5 days of incubation at initial $\mathrm{pH} 7$ and $37^{\circ} \mathrm{C}$. The previous study achieved degradation of $95.01 \%$ diesel by Trichosporon asahii [25]. Similarly Chandran and Das [26] reported that free cells of C. tropicalis able to degrade $80 \%$ of the diesel oil over a period of one week.

\section{Conclusion}

The present study focused on the degradation of diesel oil by a bacterial species isolated from diesel contaminated site. The success of oil bioremediation depends on our ability to optimize various physical, chemical, and biological conditions in the contaminated environment. Here, A. baumannii was able to degrade more than $99 \%$ of diesel oil at $\mathrm{pH} 7,35^{\circ} \mathrm{C}$ and initial hydrocarbon concentration of $4 \%$. The present study may be applied for the efficient removal of diesel oil containing industrial effluents released from petroleum refineries.

\section{Competing interests}

The authors declare that they have no competing interests.

\section{Authors' contributions}

The overall implementation of this study including experimental design, data analysis and manuscript preparation were done by NP, JR, SK and NSV. PC \& Khan critically reviewed and revised the article. All authors read and approved the final manuscript.

\section{Acknowledgement}

Authors thank Bannari Amman Institute of Technology, Sathyamangalam and SASTRA University, Thanjavur for providing facility to carry out the research work.

Received: 23 October 2013 Accepted: 22 November 2014 Published online: 12 December 2014

\section{References}

1. Kingston PF: Long-term environmental impact of oil spills. Spill Sci Technol Bull 2007, 7:53-61.

2. Gallego JLR, Loredo J, Llamas JF, Vázquez F, Sánchez J: Bioremediation of diesel-contaminated soils: evaluation of potential in situ techniques by study of bacterial degradation. Biodegradation 2001, 12:325-335.

3. Pala DM, De Carvalho DD, Pinto JC, Sant Anna Jr GL: Suitable model to describe bioremediation of a petroleum contaminated soil. Int Biodeterior Biodegrad 2006, 58:254-260.

4. Makkar RS, Rockne KJ: Comparison of synthetic surfactants and biosurfactants in enhancing biodegradation of polycyclic aromatic hydrocarbons. Environ Toxicol Chem 2003, 22:2280-2292.

5. Mukherji S, Vijay A: Critical issues in bioremediation of oil and tar contaminated sites, In: Proceedings of the International Conference on Advances in Civil Engineering. Civil Eng Dept 2002, 507-516

6. Holt JG, Krieg NR, Sneath PHA: Bergey's Manual of Determinative Bacteriology. 9th edition. Baltimore: Williamsand Wilkins; 1994.

7. Buchanan RE, Gibbons NE: Bergey's Manual of Determinative Bacteriology, (8th edition, translated in Chinese) [M]. Beijing: Science Press; 1984.

8. Zhenle T, Lihua Z, Yinghui W, Heqing T: Evalution of biodegradation of petroleum hydrocarbons pollutions by gas chromatography and spectrophotometry. Chin J Analyt Chem 2006, 34:343-346.

9. Haritash AK, Kaushik CP: Biodegradation aspects of Polycyclic Aromatic Hydrocarbons (PAHs): a review. J Hazard Mater 2009, 169:1-15.

10. Whang L-M, Liu P-WG, Ma C-C, Cheng S-S: Application of rhamnolipid and surfactin for enhanced diesel biodegradation-Effects of $\mathrm{pH}$ and ammonium addition. J Hazard Mater 2009, 164:1045-1050.

11. Xia W, Li J, Xia Y, Song Z, Zhou J: Optimization of diesel oil biodegradation in seawater using statistical experimental methodology. Water Sci Technol 2012, 66:1301-1309.

12. Luo Q, Zhang J-G, Shen X-R, Sui X, Fan Z-Q: Characterization of a novel diesel oil-degrading pseudomonas sp. strain F4. Fresenius Environ Bullet 2013, 22:689-697.

13. Sathishkumar M, Binupriya AR, Baik S-H, Yun S-E: Biodegradation of crude oil by individual bacterial strains and a mixed bacterial consortium isolated from hydrocarbon contaminated areas. Clean-Soil Air Water 2008, 36:92-96.

14. Mnif I, Sahnoun R, Ellouze-Chaabouni S, Ghribi D: Evaluation of B. subtilis SPB1 biosurfactants' potency for diesel-contaminated soil washing: optimization of oil desorption using Taguchi design. Environ Sci Pollut Res 2014, 21:851-861.

15. Luo Q, Xian-Rong S, Jian-Guo Z, Zheng-Qiu F, Ying H: Isolation, identification and biodegradation ability of diesel oil degrading Pseudomonas sp. strain C7 from bilge water. Afr J Microbiol 2012, 6:1033-1040.

16. Greenwood PF, Wibrow S, George SJ, Tibbett M: Sequential hydro- carbon biodegradation in a soil from arid coastal Australia treated with oil under laboratory controlled conditions. Org Geochem 2008, 39:1336-1346.

17. Lakshmi MB, Muthukumar K, Velan M: Immobilization of mycoplana sp. mvmb2 isolated from petroleum contaminated soil onto papaya stem (carica papaya I.) and its application on degradation of phenanthrene. Clean-Soil Air Water 2012, 40:870-877.

18. Mnif S, Sayadi S, Chamkha M: Biodegradative potential and characterization of a novel aromatic-degrading bacterium isolated from a geothermal oil 
field under saline and thermophilic conditions. Int Biodeterior Biodegrad 2014, 86:258-264.

19. Prathima Devi M, Venkateswar Reddy M, Juwarkar A, Nageswara Sarma $P$, Venkata Mohan SR: Effect of co-culture and nutrients supplementation on bioremediation of crude petroleum sludg. Clean-Soil Air Water 2011, 39:900-907.

20. Ganesh A, Lin B: Diesel degradation and biosurfactant production by Gram- positive isolate. Afr J Biotechnol 2009, 8:5847-5854.

21. Zahed MA, Aziz HA, Isa MH, Mohajeri L: Response surface analysis to improve dispersed crude oil biodegradation. Clean-Soil Air Water 2012, 40:262-267.

22. Liu CW, Chang WN, Liu H-S: Speedy Hydrocarbon Pollutants Treatment Through the Cell Interaction by a Novel Strain Rhodococcus: Its Fundamental Characteristics and Applications. Washington, DC; United States: 238th National Meeting and Exposition of the American Chemical Society, ACS; 2009.

23. Delgado JA, Follett RF: Nitrogen fate and transport in agricultural systems. J Soil Water Conserv 2002, 57:402-407.

24. Bautista LF, Sanz R, Molina MC, González N, Sánchez D: Effect of different non-ionic surfactants on the biodegradation of PAHs by diverse bacteria. Int Biodeter Biodegr 2009, 63:913-922.

25. Ilori MO, Adebusoye SA, Ojo AC: Isolation and characterization of hydrocarbon degrading and biosurfactant producing yeast strains obtained from lagoon water. World J Microbiol Biotechnol 2008, 24:2539-2545

26. Chandran P, Das N: Degradation of diesel oil by immobilized Candida tropicalis and biofilm formed on gravels. Biodegradation 2011, 22:1181-1189.

doi:10.1186/s40201-014-0142-2

Cite this article as: Palanisamy et al: Diesel biodegradation capacities of indigenous bacterial species isolated from diesel contaminated soil. Journal of Environmental Health Science \& Engineering 2014 12:142.

\section{Submit your next manuscript to BioMed Central and take full advantage of:}

- Convenient online submission

- Thorough peer review

- No space constraints or color figure charges

- Immediate publication on acceptance

- Inclusion in PubMed, CAS, Scopus and Google Scholar

- Research which is freely available for redistribution 